\title{
Applied Entomology and Zoology Vol. 54, No. 3 目次
}

(2019 年 8 月 25 日発行)

\section{ORIGINAL RESEARCH PAPERS}

Cost-effective sampling for estimating species richness of ground beetles (Coleoptera: Carabidae) using pitfall traps: efficiency of non-parametric species richness estimators [ピットフォールトラップで採集したオサムシ類（コウチュウ目： オサムシ科) の種数推定のための効率的なサン プリング：ノンパ ラメトリック種数推定手法の効率]

S. Yamanaka · Y. Hironaka - K. Ozaki (山中 聡 · 弘中 豊 · 尾崎研一) 231

Greater degree of body size plasticity in males than females of the rhinoceros beetle Trypoxylus dichotomus $[$ カブ トムシ (コウチュウ目：コガネムシ科) の体サイズの可塑性はメ スよりもオスの方が大きい]

W. Kojima (小島 渉) 239

Meta-analysis of the damage suppression effect of a double-layer fruit protection bag on fruit bug injuries of loquat fruits and evaluation by explicit solution of odds ratio[果樹カメムシ類によるビワ果実への加害を軽減する二重果 実袋の被害抑制効果に関するメタアナリシスとオッズ比の陽的展 開による評価]

K. Shimizu $\cdot$ T. Kawana $\cdot$ T. Ohtani $\cdot$ T. Mihira $\cdot$ S. Furukawa （清水 健 · 河名利幸 ·大谷 徹 · 三平東作 ·古川誠司） 247

Effects of radiofrequency on the development and performance of Callosobruchus chinensis (Coleoptera: Chrysomelidae: Bruchinae) on three different leguminous seeds [3つの異なるマメ科種子におけるアズキゾウムシ（コウ チュウ目：ハムシ科：マメゾウムシ亜科) の発育や増殖パフォー マンスにラジオ波が及ぼす影響]

Rameswor Maharjan · Hwijong Yi · Jeongjoon Ahn · Gwang Hyun Roh · Chunggyoo Park - Youngnam Yoon · Yunwoo Jang $\cdot$ Inyoul Baek $\cdot$ Yongchul $\mathrm{Kim} \cdot$ Soondo Bae 255

Development of magnetic attraction systems to mark and recapture a medically important vector, Haemaphysalis longicornis (Acari: Ixodidae) [医学的に重要な媒介者フタトゲ チマダニ (ダニ目：マダニ科) を標識再捕するための磁力システ 么の開発]

Hyunsung Song · Donghyun Lim · Jung-Wook Kho · DooHyung Lee $\mathbf{2 6 7}$
Previous exposures to cues from conspecifics and ladybird beetles prime antipredator responses in pea aphids Acyrthosiphon pisum (Hemiptera: Aphididae) [捕食者に襲わ れる同種からのキューを前もって受容したエンドウヒゲナガアブ ラムシ (カメムシ目：アブラムシ科) による対捕食者反応の準備] K. Tamai · Y. Choh (玉井一彦・長 泰行) 277

Estimation of dispersal distance of the soybean pod borer Leguminivora glycinivorella (Lepidoptera: Tortricidae) by mark-recapture experiments [標識再捕法によるマメシンクイ ガ (チョウ目：ハマキガ科) の移動分散距離の推定］

H. Takeuchi · N. Endo · K. Yamamura（竹内博昭・遠藤信幸 · 山村光司） 285

Identification of methyl 6-methylsalicylate as the trail pheromone of the Japanese pavement ant Tetramorium tsushimae (Hymenoptera: Formicidae) [トビイロシワアリ(ハチ 目：アリ科) の道しるべフェロモン：6-メチルサリチル酸メチル の同定]

T. Nakamura - K. Harada - T. Akino (中村哲朗 - 原田恭子 - 秋 野順治） 297

Developmental properties and parasitism capacity of the egg parasitoid Trissolcus japonicus (Hymenoptera: Scelionidae), reared on eggs of Glaucias subpunctatus (Hemiptera: Pentatomidae) [ツヤアオカメムシ（カメムシ目 : カメムシ科) の卵で飼育した卵寄生蜂 Trissolcus japonicus (八チ目: タマゴクロバチ科) の発育特性と寄生能力]

D. Kuki · Y. Wada · A. Tsunashima - K. Itoyama（九鬼奈紀 · 和田芳樹・綱島彩香・糸山 享) 307

Development and reproduction of the parasitic wasp Allotropa subclavata (Hymenoptera: Platygasteridae) on the Japanese mealybug Planococcus kraunhiae (Hemiptera: Pseudococcidae) [フジコナカイガラムシ (カメムシ目 : コナカイ ガラムシ科) の捕食寄生蜂フジコナカイガラクロバチ (ハチ目 : ハラビロクロバチ科) の発育打よび増殖]

M. Teshiba · S. Kawano • M. Tokuda ・ M. Takagi (手柴真弓 · 河野聡子・徳田 誠・高木正見） 313

\section{TECHNICAL NOTE}

Rapid detection of the red fire ant Solenopsis invicta 
(Hymenoptera: Formicidae) by loop-mediated isothermal amplification [LAMP 法によるヒアリ（ハチ目：アリ科）の迅速 検出法の開発]
N. Nakajima · Y. Sakamoto - K. Goka（中鴆信美 - 坂本佳子 · 五箇公一) 319 